UDC 629.3.025.2(045)

DOI:10.18372/1990-5548.65.14989

${ }^{1}$ O. A. Sushchenko, ${ }^{2}$ A. A. Salyuk,

${ }^{3}$ S. H. Yehorov

\title{
FEATURES OF MODELLING STABILIZATION DIGITAL SYSTEM OF GROUND VEHICLE EQUIPMENT
}

Faculty of Air Navigation, Electronics and Telecommunications, National Aviation University, E-mails: ${ }^{1}$ sushoa@ukr.net ORCID 0000-0002-8837-1521, 22 sashalok511@gmail.com,

3avionika2006@ukr.net

\begin{abstract}
Features of development models and modeling of stabilization systems of ground vehicle equipment are considered. Features of the optimal synthesis procedure for the system of the considered type are mentioned. The main goal of the research is to study the design features of the stabilization system with the digital control unit. Two approaches to the discretization of a system with the digital control unit are given. Appropriate block-diagrams are represented. Analysis of sampling methods and appropriate software is given. Possible program realizations of transfer functions in a model of the digital control unit are discussed. Features of representation of digital filters unit are proposed. Modelling of the stabilization system with the digital control unit was carried out. Simulation results are represented. Transient processes on the angular rate with different ways of sampling are given. Results of the comparative analysis of different sampling ways are shown in the tabular form. The obtained results can be useful for designing control systems of the wide type.
\end{abstract}

Index Terms-Digital control unit; digital filter; discretization; ground vehicle equipment; stabilization system.

\section{INTRODUCTION}

The creation of new perspective systems for stabilization of ground moving vehicles is increasingly important. The development of such systems requires the applying methods of analysis and synthesis. A significant number of such methods are focused on linear systems. It should be noted that the results of simulation of a linearized model coincide with the results of simulation of a more accurate and complex nonlinear model in many situations.

Also, the process of creating a model focused on a real system is quite complex and can lead to errors comparable to the errors of linearization [1].

The first method of A. M. Lyapunov can be taken as a theoretical basis for the possibility of using linear models for the synthesis of control systems.

According to this method, the stability of a nonlinear system can be researched as a first linear approximation under the condition of smooth linear characteristic [2].

It should be noted that the widely developed apparatus of software tools for analysis and synthesis of designing optimal systems (Control System Toolbox, Robust Control Toolbox) is based on linear time-invariant models.

Using this approach, it is necessary to satisfy the technical requirements for the system with some margin taking into consideration unaccounted nonlinearities.

Extensive use of computing tools is a modern trend in the design of control systems of a wide class in general and stabilization systems in particular. These reasons condition the need of developing models and simulation of stabilization systems with a digital control unit. At the same time some features are need.

\section{ANALYSIS OF PREVIOUS STUDIES AND PROBLEM STATEMENT}

Approaches to the parametric optimization of control systems of moving vehicles are represented in many textbooks and papers, for example [3].

Theoretical fundamentals of calculating procedures for optimal synthesis of robust aircraft control systems based on the mixed $H_{2} / H_{\infty}$ approach are given in [3], [4]. This approach takes into consideration requirement to both robust performance and robustness of the synthesized system at the same time.

The algorithm of the synthesis of the systems assigned for stabilization of measuring-observation equipment operated on ground vehicles [5]. The full mathematical description of the stabilization system of ground vehicle equipment is represented in [6]. Analysis of the basic linearities of this mathematical 
description and approaches to linearization of the model are given in [7].

Features and results of simulating stabilization systems of ground vehicle measuring-observation equipment with continuous control unit are represented in [8]. Software for simulation of stabilization systems of ground measuringobservation equipment were researched in [9].

Ways of discretization of continuous control systems are described in many publications, for example, [10]. The possibilities of modern computer technique for discretization of continuous systems of the wide class are researched in [11]. Development of the stabilization system with a discrete control unit requires researching new approaches and specific research.

The goal of this article is determination of approaches to simulation of the stabilization system of ground vehicle equipment with a digital control unit and representation of simulation results based on these approaches.

\section{FEATURES AND RESULTS OF SIMULATION OF STABILIZATION SYSTEM WITH DIGITAL CONTROL UNIT}

The problem of parametric optimization of systems of motion control of the wide class in general and stabilization system in particular requires using quality criteria in three aspects. Firstly, solving this problem requires forming the objective function. Secondly, optimization problems of the studied type require using a penalty function. Thirdly, a feature of these problems is the necessity of analysis of the obtained results with using various quality criteria.

Synthesis of system resistant to disturbances can be based on minimization of the $H_{\infty}$-norm of the matrix transfer function of the closed-loop control system. It is known also approach, which is based on minimization of the $\mathrm{H}_{2}$-norm of the matrix transfer function of the closed-loop system that characterizes the accuracy of the system. It should be noted that, from the point of view of implementing calculation algorithms, $H_{\infty}$-optimization is more complex in comparison with $\mathrm{H}_{2}$-optimization. This is caused by the necessity of using a search procedure. Methods of synthesis based on minimization of $\mathrm{H}_{2}$-norm provide the high accuracy of the synthesized system but such a system stays sensitive both to external disturbances and parametrical disturbances of the stabilization plant. Application of the $H_{\infty}$-norm allows providing system stability to the external disturbances in conditions of structured and non- structured parametric uncertainties. Optimization by each of approaches has definite advantages. But optimization by the mixed criterion provides combination of the above-mentioned advantages [3], [4]. In this case, the synthesized system will be characterized by the optimal quality in conditions of functioning under influence of disturbances.

Researching stabilization systems with digital control units is of great importance due to the widespread application of digital computing devices in modern control systems in general and stabilization systems in particular.

In such a system, a digital control unit is based on the computer or microprocessor. The stabilization plant is considered to be continuous. At the same time, the digital control unit of the stabilization system implements a law of stabilization and control of stabilization plant angular motion. Hence, a continuous stabilization with a digital control unit represents a hybrid system. There are two approaches to researching such a system [12].

In the first case, to research a system, it is necessary to transform a model as a single discrete mathematical description of both the stabilization plant and the digital control unit.

In the second case, researching a continuous system and, respectively, synthesis of continuous stabilization laws is carried out. Further transformation of continuous laws into discrete is implemented. Moreover, research of dynamics of the obtained continuous-discrete system is necessary. The second approach is called "a method of continuous models" [12]. It is convenient to use the second approach for solving problems of the synthesis of digital stabilization systems having analog prototypes.

It should be noted that the development of methods of researching modern control systems in general and stabilization systems, in particular, is impossible without using means of automated design. Usually, the process of designing complex control systems at early phases of development requires using two types of mathematical models such as linear and non-linear. Linear models are necessary for carrying out procedures of analysis and synthesis of the designed system. Non-linear models allow us to simulate stabilization processes similar to functioning real systems. Furthermore, non-linear models provide checking results of appropriate procedures of analysis and synthesis.

As is stated in [13], MATLAB is the most qualified tool for simulation of the system of the researched type. The linear models in MATLAB can be developed based on of Control System Toolbox, Robust Control Toolbox. Nonlinear models can be 
created using Simulink. Taking into consideration these features, it is possible to develop a technique of creating stabilization system with digit control unit. This technique includes following steps.

1) Determination of basic principles of developing stabilization system with the digital control unit is implemented. Having the experience of previous developments, it is advisable to determine the principles of synthesis of a stabilization system with a continuous control unit with its subsequent conversion into digital control unit.

2) Parametric or structural and parametric optimization of the linear stabilization system with the digital control unit based on procedures of the optimal synthesis with discretization of stabilization plant is carried out. The used software includes Control System Toolbox and Robust Control Toolbox, which are components of MATLAB.

3) The analysis of performances of the synthesized digital stabilization system taking into consideration nonlinearities inherent to real systems is performed. The analysis is carried out based on the continuous stabilization plant with simulation of analog-digital and digital-analog conversion processes using Simulink Toolbox of the system MATLAB. At this step, simulation of basic autonomous tests using the non-linear model of the synthesized stabilization system taking into consideration nonlinearities inherent to real systems.

The development of stabilization systems based on the continuous prototype is of great importance for devices of the researched type. Such an approach allows us to use previous achievements in the creation of stabilization systems of ground vehicle equipment. Moreover, in some cases, it is necessary to create digital filters on the basis of continuous analogs. To solve this problem, it is proposed to develop the mathematical model of the stabilization system with the continuous control unit by means of transfer functions, for example, using known analytic dependencies for separate electrical schemes. This process is sufficiently difficult. The correctness of the analytic representation must be checked by appropriate tests using the tested bench. In this case, it is convenient to use modern systems of simulating electronic devices, for example, Electronics WorkBench or MultiSIM, which allow us to determine logarithmic amplitude-frequency characteristics of transfer functions of electrical schemes. Further, it is necessary to compare the obtained characteristics with similar characteristics of transfer functions obtained in an analytical way, for example, by means of MATLAB. After the representation of the continuous control unit in the form of the mathematical model on the basis of transfer functions, it is possible to implement conversion in the discrete unit by means of $z$-transform using MATLAB software. The choice of the method and period of discretization is implemented on the basis of the necessary accuracy of conversion that can be estimated by the degree of coincidence of logarithmic amplitude-frequency characteristics of discrete transfer functions with similar characteristics of continuous transfer functions. It should be noted that the digit transfer function of the integrator. In this case, it is convenient to use the bilinear transform, which is sufficiently accurate.

The above-mentioned approach includes the following sequence of operations.

1) Simulation of the electrical circuit diagram of the electronic device, for example, by means of Electronics Workbench.

2) Plotting logarithmic amplitude-frequency characteristics and phase-frequency characteristics of the electronic device in system Electronics Workbench, and analysis of the obtained results.

3) The analytical approximation of the electrical circuit diagram of the electronic device by the transfer functions.

4) Checking the obtained results by tests using the tested bench with the following plotting amplitude-frequency characteristics of the researched electronic device.

5) The choice of sampling period based on Kotelnikov theorem and requirements to the hardware of the stabilization system.

6) The choice of discretization method based on requirements to accuracy of the continuous-discrete transformation.

7) Transformation of continuous models of electronic devices into digital by means of the function $c 2 d$ (MATLAB).

8) Representation of transfer functions of separate units in the form of the digital filters.

9) Plotting logarithmic amplitude-frequency and phase-frequency characteristics by means of MATLAB.

10) Comparison of appropriate logarithmic amplitude-frequency and phase-frequency characteristics with the experimental results, and correction of the obtained transfer functions.

Results of simulation of the stabilization system with the digital control unit on the basis of a model, which takes into consideration all the non-linearities inherent to real systems, are represented in Fig. 1.

The discretization of phases of parametrical and structural-parametrical optimization and analysis of the synthesized stabilization system have some differences, as it is shown in Fig. 2. 


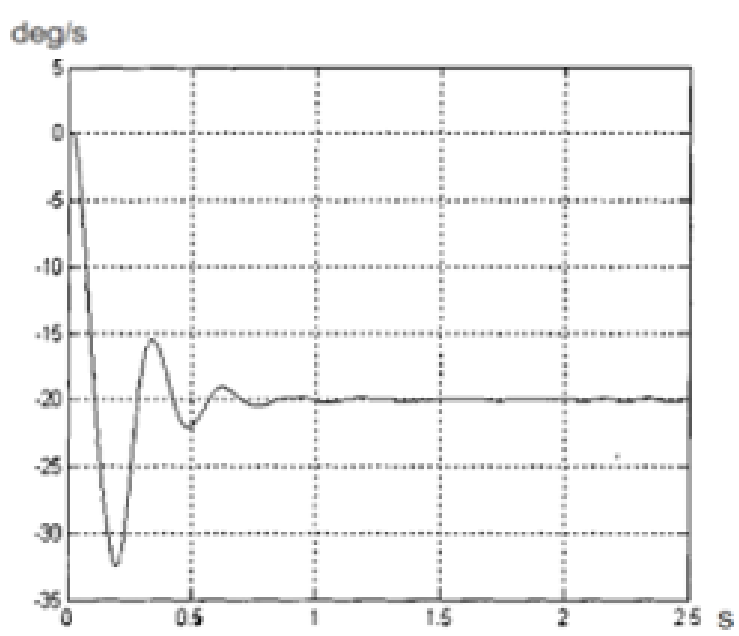

a)

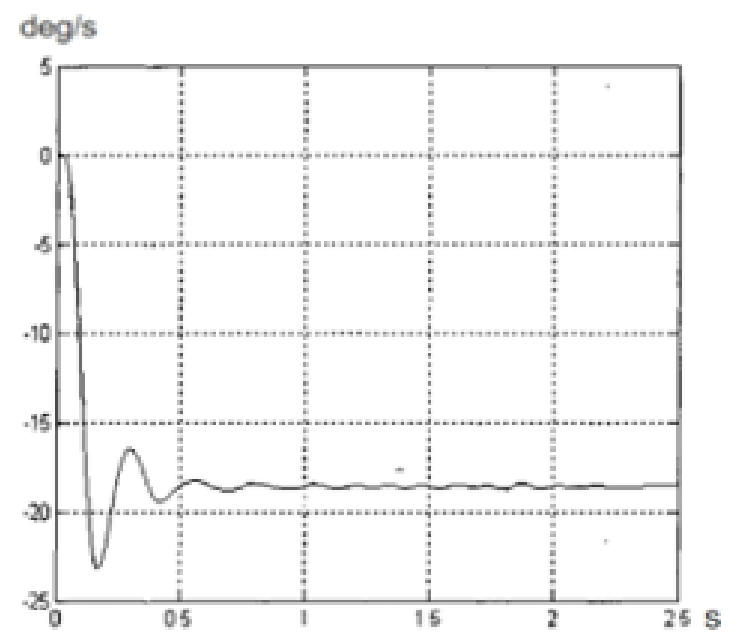

c)

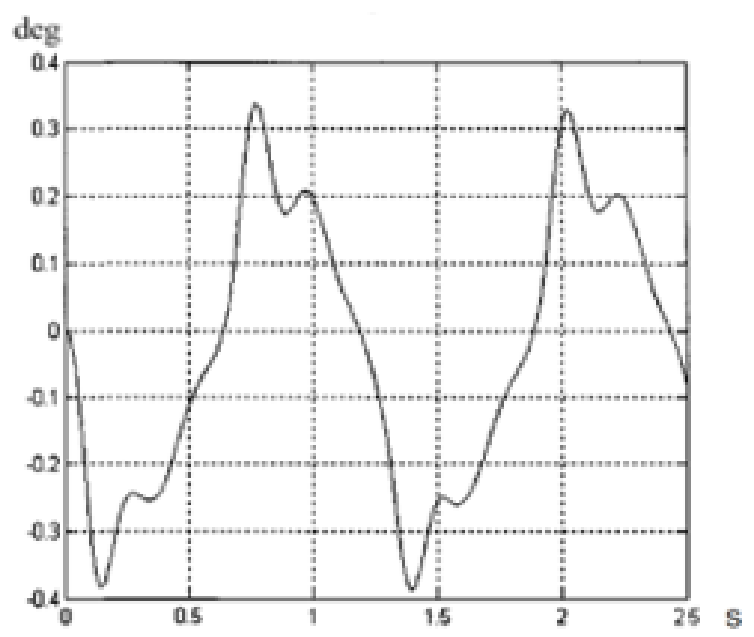

e)

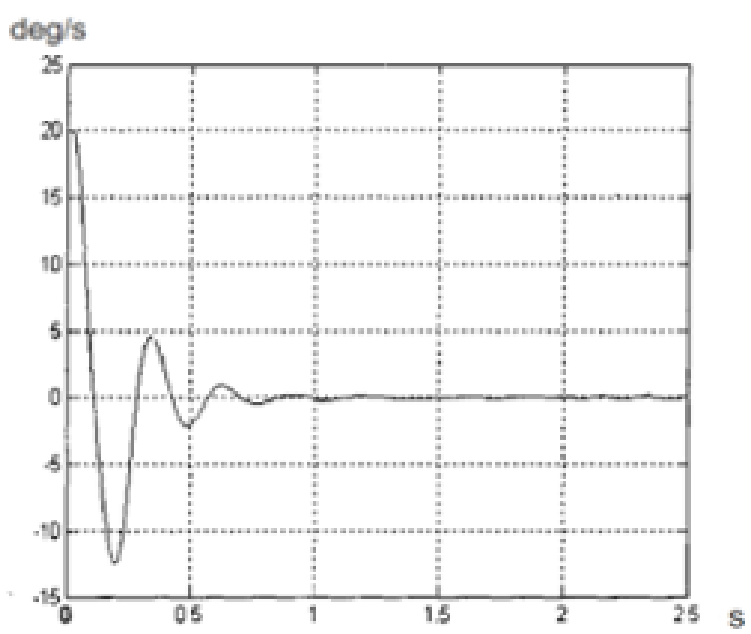

b)

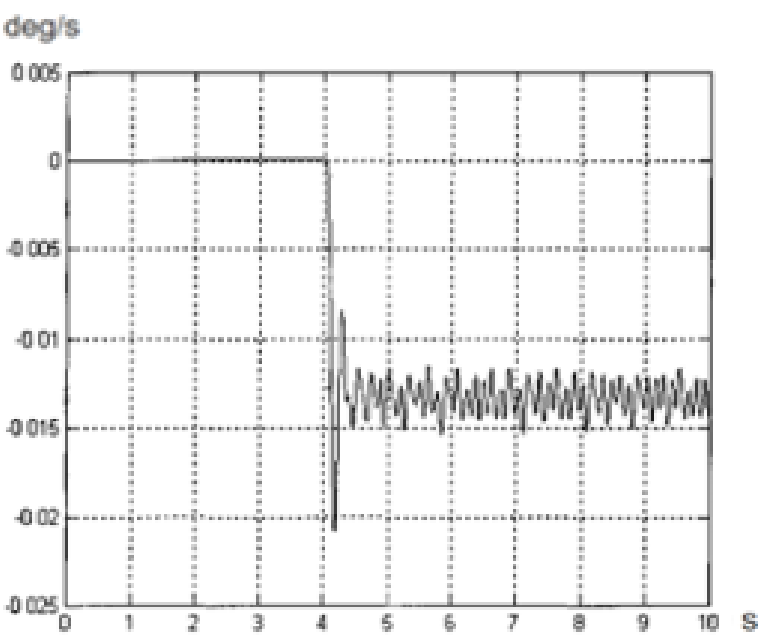

d)

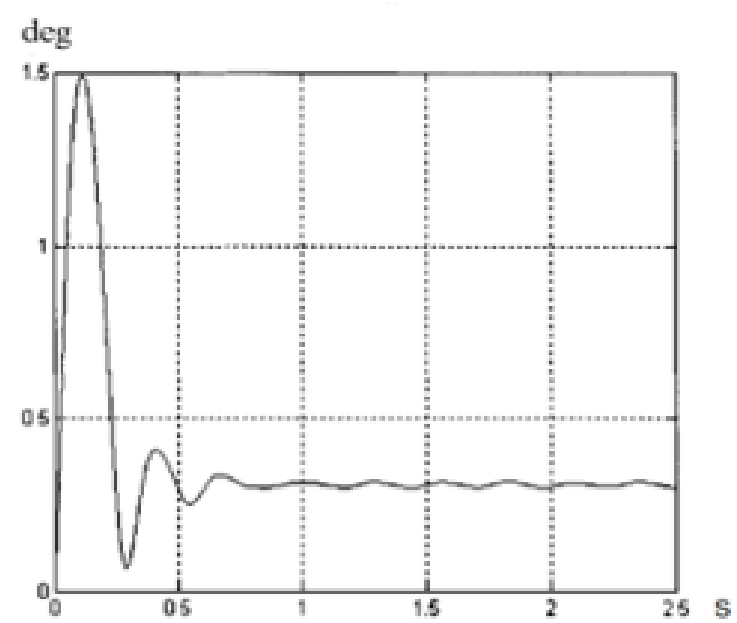

f)

Fig. 1. Results of simulation of stabilization system: (a) is the transient process on the angular rate $20 \mathrm{deg} / \mathrm{s}$ in stabilization mode (translation angular rate); (b) is the transient process on the angular rate $20 \mathrm{deg} / \mathrm{s}$ in stabilization mode (absolute angular rate); (c) is the transient process of the signal, which is given from operator console in the tracking mode; (d) is the transient process of the small-signal, which is given from the operator console; (e) is the transient process on the absolute angle for the given harmonic rate $0.22 \cos (5.02 \mathrm{t}+\pi / 2)$; (f) is the transient process on an absolute angle for the given speed of translation $20 \mathrm{deg} / \mathrm{s}$ in the stabilization mode 


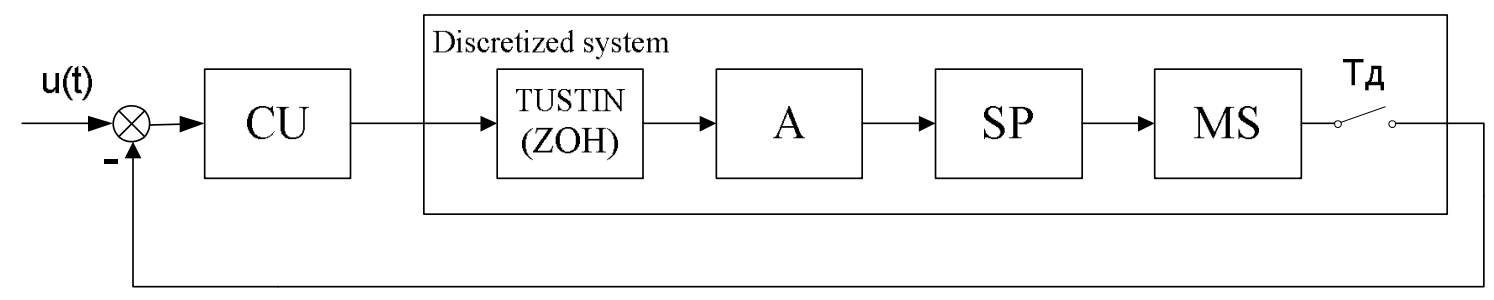

a)

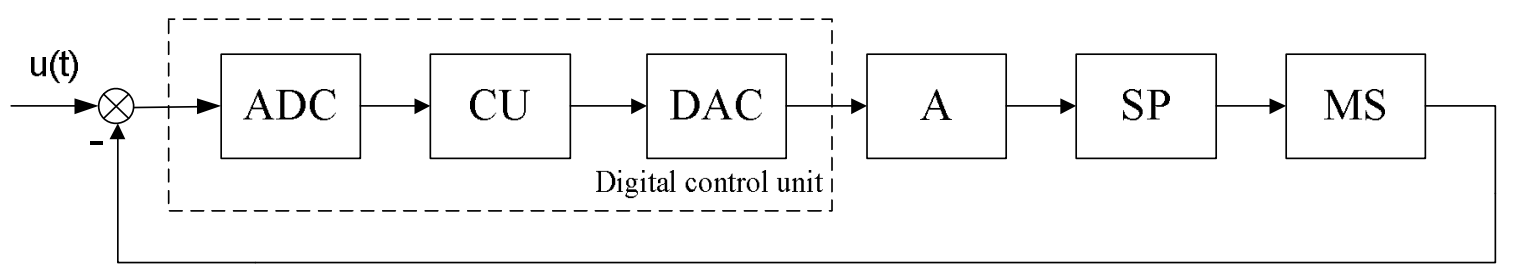

b)

Fig. 2. Features of sampling stages of synthesis $(a)$ and analysis $(b)$ for stabilization system with the digital control unit: $\mathrm{CU}$ is the computing unit; $\mathrm{A}$ is the actuator; SP is the stabilization plant; MS is the measuring system; $\mathrm{ZOH}$ is the extrapolator of the zero-order; Tustin is the bilinear approximation; $T_{s}$ is the sampling period

As follows from the structural schemes represented in Fig. 2, in the first case, the discretization of the stabilization plant is carried out, in the second case, the stabilization plant is continuous but processes of analog-digital and digital-analog transformations are carried out. The necessity to carry out discretization of the stabilization system causes key problems. Firstly, it is necessary to determine sampling time, secondly, we must choose a method of discretization.

There are many approaches to solving the first problem. The most widespread way is applying Kotelnikov theorem. The sampling time of a continuous system must satisfy the condition [14]

$$
f_{s} \leq 1 /\left(2 f_{b}\right),
$$

where $f_{s}$ is the sampling frequency; $f_{b}$ is the boundary frequency.

Numerical values of these frequencies can be chosen using experimental results. Based on the results of experimental tests carried out during the development of prototypes of the created system, $f_{b}$ is equal to $200 \mathrm{~Hz}$. Hence, the period of sampling $T_{s}$ should be no less than $0.0025 \mathrm{~s}$. The similar results can be achieved by means of an approach represented in [15]. In accordance with this approach, the sampling period is chosen on the basis of the desired bandwidth by the expression

$$
\omega_{s}=2 \pi f_{s}=(6-25) \Delta \omega_{b}=(6-25) 2 \pi \Delta f_{b},
$$

where $\Delta f_{b}$ is the bandwidth, which in this research is equal to $400 \mathrm{~Hz}$.

Hence,

$$
\frac{1}{4 \Delta f_{b}}<T_{s} \leq \frac{1}{\Delta f_{b}} \text { or } 0.000625<T_{s} \leq 0.0025 .
$$

The above-mentioned suppositions lead to the necessity to choose a value of $0.0025 \mathrm{~s}$ as the sampling period.

It should be noted that in terms of providing accurate requirements for transient processes, it would be even better to use a frequency of $0.00125 \mathrm{~s}$, but this choice leads to some difficulties in hardware implementation.

Modeling based on the model of the stabilization system taking into account the nonlinearities inherent in real systems and the processes of analogto-digital and digital-to-analog transformations for different sampling periods such as $\tau_{1}=0.001 \mathrm{~s}$, $\tau_{2}=0.0025 \mathrm{~s}$, and $\tau_{3}=0.005 \mathrm{~s}$ has been shown that the differences in the transient processes for sampling periods $\tau_{1}, \tau_{2}$ are not significant. And the quality of transient processes of both these transient processes is better in comparison with period $\tau_{3}$. Therefore, it is convenient to choose the sampling period $\tau_{2}=0.025 \mathrm{~s}$.

The sampling period of pulse-width-modulators in the channel of control of the stabilization system actuator is also equal to $\tau_{\mathrm{PWM}}=0.025 \mathrm{~s}$. This allows us to decrease the influence of errors due to information converting by means of synchronizing frequency of renewing information in the digital control unit and amplifier of the actuator control channel.

In conditions of using such stabilization system hardware as 16-bit ADC on the range of input 
control signals until $10 \mathrm{~V}$, the conversion of information will be occurred with a sampling of signals by an amplitude $0.3 \mathrm{mV}$ or $0.0011 \mathrm{deg} / \mathrm{s}$ (in the range $\pm 35 \mathrm{deg} / \mathrm{s}$ ).

Applying the representation of the plant model in the discrete form by means of the function $c 2 d$, it is possible to write the recurrent relationships of the system as follows [9]

$$
\begin{gathered}
\mathbf{x}(k+1)=\mathbf{A}_{\mathrm{d}} \mathbf{x}(k)+\mathbf{B}_{\mathrm{d}} \mathbf{u}(k) ; \\
\mathbf{y}(k)=\mathbf{C} \mathbf{x}(k)+\mathbf{D u}(k),
\end{gathered}
$$

where $\mathbf{x}$ is the vector of state variables; $\mathbf{A}_{\mathrm{d}}, \mathbf{B}_{\mathrm{d}}, \mathbf{C}, \mathbf{D}$ are matrices of state, control, measurements, and disturbances; $\mathbf{u}$ is the vector of controls; $\mathbf{y}$ is a vector of measurements, here all vectors and matrices are fixed at instants of time $k T_{s}, k=0,1, \ldots, T_{s}$ is the sampling period.

It is possible to use different methods for system discretization and extrapolation. Control System Toolbox implements some methods including extrapolation of the zero $(\mathrm{ZOH})$ and first $(\mathrm{FOH})$ orders, impulse-invariant discretization (IMP), bilinear fractionally rational Tustin approximation (TUSTIN) and with correction by frequency (PREWARP), and method of reproduction of poles and zeros (MATCHED) [4]. The last method can be applied for one-dimensional systems only. During approximation of the zero-order, signals are approximated in the middle of the system sampling interval by a constant equal to a value at beginning of the sampling interval. During the extrapolation of the first order, input signals are approximated by straight-line segments in the sampling interval.

Robust Control Toolbox implements the conversion of a continuous system into a discrete system by the bilinear transformation. This can be realized by seven methods. The most widespread methods are bilinear transformation TUSTIN and inverse methods of rectangles BWDREC.

The development of a discrete model of a continuous system by extrapolator of the zero-order is implemented in the following way. The discrete signal $u[k]$ enters the unit $\mathrm{ZOH}$, which generates a continuous signal $u(t)$ using extrapolation of every discrete value by a constant level during one sampling period $u(t)=u[k]$ for $k T_{s} \leq t<(k+1) T_{s}$. This signal enters the input of the continuous system with transfer function $H(s)$. System output $y(t)$ is sampled with the period $T_{s}$. As a result, the signal $y[k]$ is formed. More accurate transformation is the bilinear Tustin approximation, which uses the approximate relationship for exponent [4]

$$
z=e^{s T} \cong \frac{1+s T_{s} / 2}{1-s T_{s} / 2},
$$

which is used for determining the connection between variables $s$ and $z$ for continuous and discrete transfer functions. The continuous transfer function is converted into discrete $H_{d}(z) \cong H(s)$ by means of substitution

$$
s \cong \frac{2}{T_{s}} \frac{z-1}{z+1}
$$

The Tustin method with correction uses the following substitution

$$
s \cong \frac{\omega}{\operatorname{tg}\left(\omega T_{s} / 2\right)} \frac{z-1}{z+1} .
$$

There are different forms of representing discrete transfer functions both in the automatic control theory and signal digital processing [4]. The automatic control theory uses the variable $z$ and polynomials of the nominator and denominator are arranged in order of decreasing degrees of these polynomials. The variable $z^{-1}$ is used in signal digital processing. This is caused by the simpler technical implementation of this way of representing the discrete transfer function in programming computing devices. It is obvious that developing a procedure of optimal parametric synthesis for the discrete system must be carried out taking into consideration real implementations of control units, where the representation of transfer functions for discrete controllers as a function of the variable $z^{-1}$ is generally accepted.

In the general case, the control unit can include both continuous and discrete units. For representing the plant and continuous units of the discrete controller, it is convenient to use $z$-transform of the first type. Respectively, $z$-transform of the second type can be used for representing units of the digital part of the controller.

It should be noted that in the case of using Control System Toolbox, representing transfer function of a continuous unit into appropriate transfer function in the form of the digital filter can be implemented by means of two MATLAB functions such as $c 2 d$ (transformation of continuous $t f$-models into discrete) and filt (creation of $t f$-model in the form of the digital filter). The choice of the method of discretization and extrapolation 
influences significantly on the accuracy of discretization of the stabilization system of ground converting a continuous model into a discrete one.

Results of the application of the extrapolator of the zero-order and bilinear approximation for the

vehicle equipment are represented in Fig. 4.

Results of comparative analysis of applying different types of discretization are represented in Table I.

TABLE I. RESUlts of COMPARATIVE ANALYSIS OF DifFERENT WAYS OF DiscReTIZATION

\begin{tabular}{|l|c|c|c|c|}
\hline & $H_{2}$ & $H_{\infty}$ & $\Delta A, \mathrm{~dB}$ & $\Delta \varphi, \mathrm{deg}$ \\
\hline Continuous model & 0.3182 & 0.1261 & 59.4 & 91.1 \\
\hline Model discretized by ZOH method, $T_{s}=0.00125 \mathrm{~s}$ & 0.4670 & 0.1866 & 50.2 & 91.1 \\
\hline Model discretized by Tustin method, $T_{s}=0.00125 \mathrm{~s}$ & 0.3281 & 0.1251 & 59.4 & 91.1 \\
\hline Model discretized by Tustin method, $T_{s}=0.0025 \mathrm{~s}$ & 0.3389 & 0.1263 & 59.4 & 91.1 \\
\hline
\end{tabular}

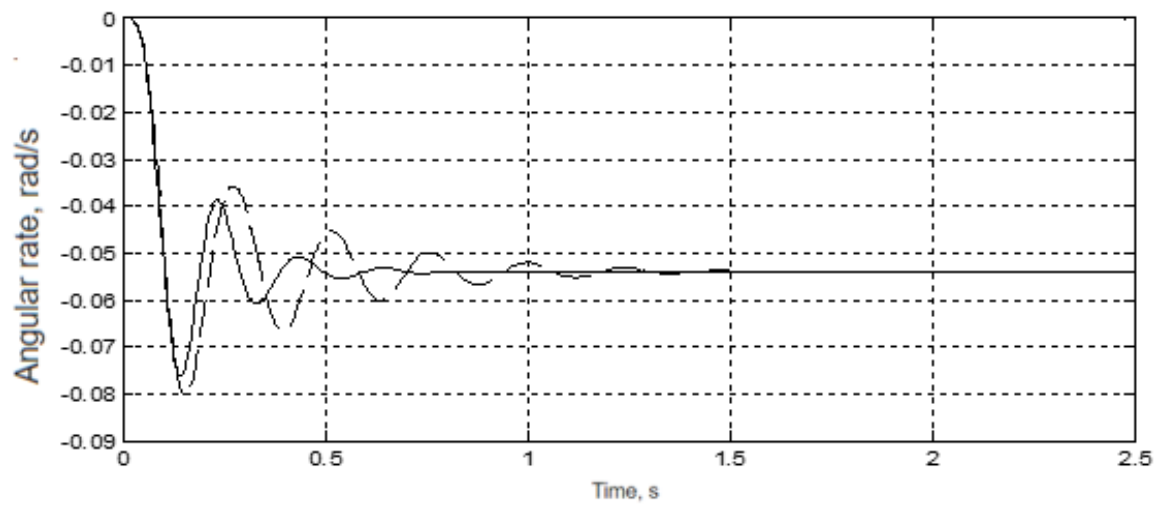

a)

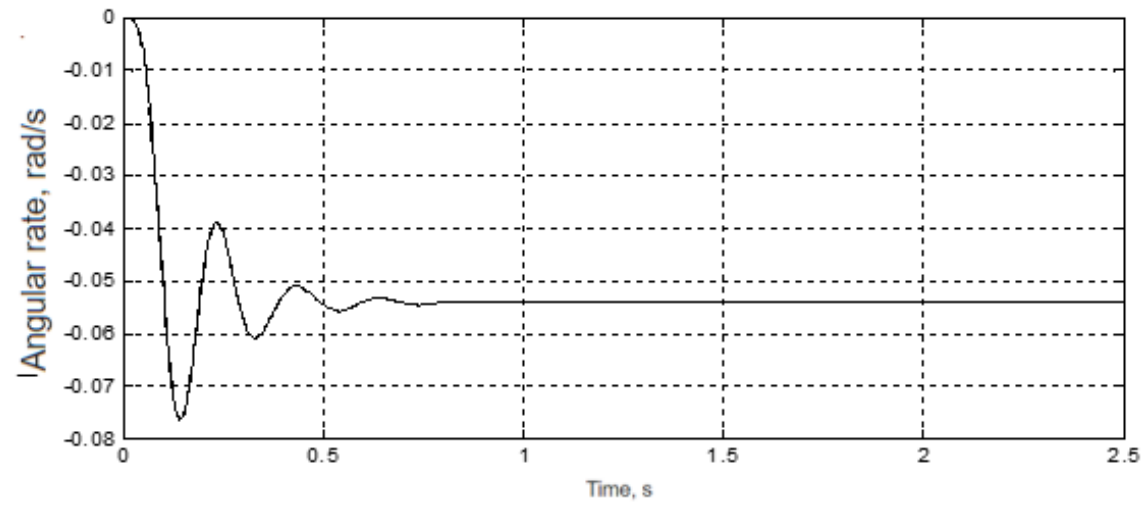

b)

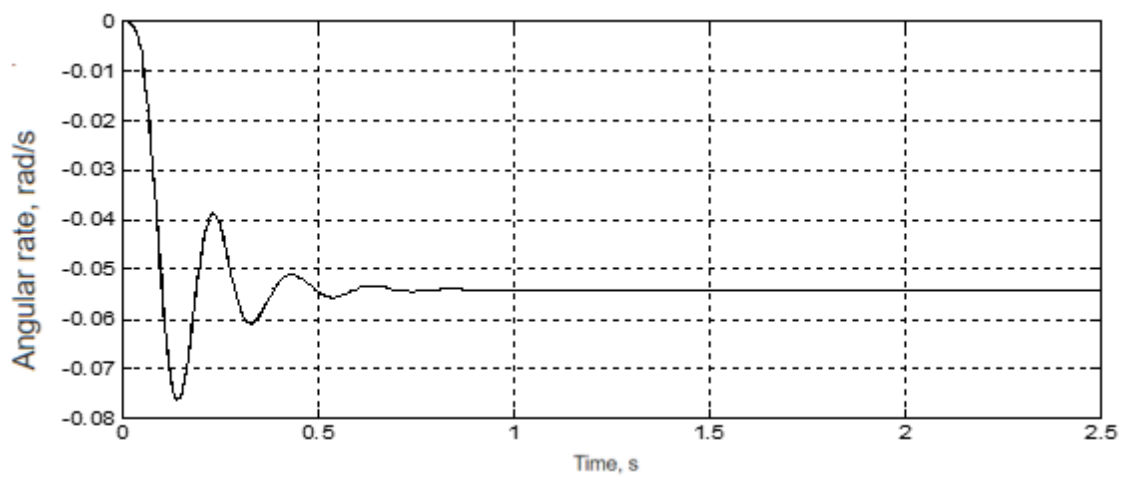

c)

Fig. 3. Transient process of angular rate for continuous (solid line) and discretized (dash line) stabilization systems: (a) is the discretization by the extrapolator of the zero-order; (b) is the discretization by bilinear Tustin approximation with sampling period $0.0025 \mathrm{~s}$; (c) is the discretization by bilinear Tustin approximation with sampling period $0.00125 \mathrm{~s}$ 
Hence, the Tustin method is the most convenient for the discretization of the system of the researched type. With regard to the study of separate units, it should be noted that the process of integration is the most sensitive to the choice of the sampling method. In this case, it is necessary to use a comparatively accurate bilinear approximation.

Both continuous and discrete models can be used at the stage of analysis of characteristics of the synthesized stabilization system. Such an approach allows simulating processes similar to ones, which occur in a real system. The possibility of using models of saturation, nonlinearity zone, analog-todigital converter, and pulse-width modulator deserves the greatest attention. The feature of discretization at this stage is the necessity to simulate analog-digital and digital-analog conversions. The analog-digital conversion can be simulated in accordance with the scheme represented in Fig. 4. Such an approach provides both the sampling of signals in time and the fixation of the definite signal level during sampling time.

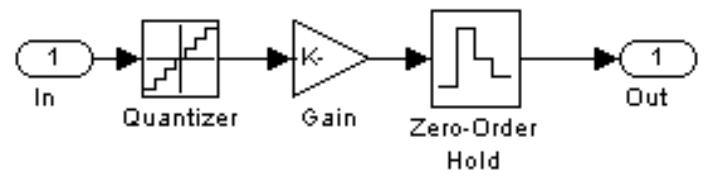

Fig. 4. The calculating scheme of the analog-digital transform

The inverse digit-analog conversion similar to processes that occurred in a real system can be implemented by means of Simulink Toolbox. Simulation of the discretization process must take into consideration such a device of a stabilization system as a pulse-width-modulator. The model of this unit can be represented by the formula

$$
\frac{1}{z} \frac{N 100 \%}{N_{\max }}
$$

where $\frac{1}{z}$ is an operator, which takes into consideration delay of the control unit; $N$ is the input signal of the digital control unit; $N_{\max }$ is the value of the maximum digital signal. The abovementioned formula allows determining a width of the output impulse relative to the input signal. Further, the control signal of the actuator is formed on the basis of known voltage amplitude $(27 \mathrm{~V})$ and the obtained sequence of impulses using MATLAB function square.

The digital-analog conversion can be simulated by the calculating scheme represented in Fig. 5 .

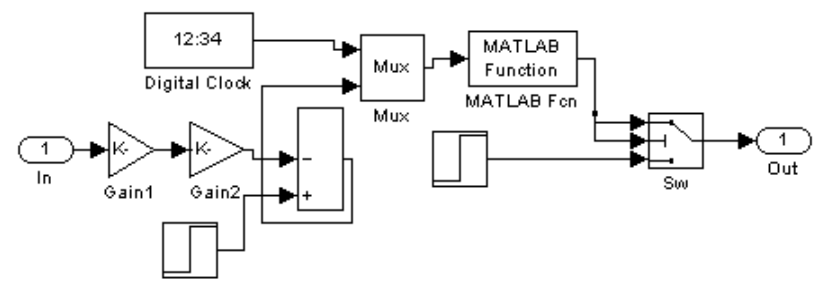

Fig. 5. The calculating scheme of digital-analog conversion

Modelling based on mathematical description including the continuous plant model and the discrete model of the control unit provides the simulation of the researched system.

\section{CONCLUSIONS}

The basic principles of simulation of the stabilization system with the digital control unit assigned for the stabilization of ground vehicle equipment are considered.

The method of representing discrete units in conditions of the presence of continuous prototypes is given.

The main differences in the sampling of models of the stabilization system at the stages of synthesis and analysis of the obtained results are represented.

The effectiveness of the proposed approaches is confirmed by the simulation results.

\section{REFERENCES}

[1] B. P. Demidovich, Lectures on Mathematical Theory of Stability, Moscow: MSU, 1998, $342 \mathrm{p}$.

[2] B. R. Andrievsky and A.L. Fradkov, Chosen Chapters of Automatic Control Theory with Examples on MATLAB, Saint-Petersburg: Nauka, $2000,475 \mathrm{p}$.

[3] A. A. Tunik, R-Hyu, I. K. Ahn, and C. H. Lim, "Parametric Optimization Procedure for Robust Flight Control System Design," in Proceedings of the KSAS Fall Annual Meeting, 2000, Daejeon, Korea, pp. 293-300.

[4] A. Tunik, Hyeok Ryu, and Hae-Chang Lee, "Parametric optimization procedure for robust flight control system design," KSAS International Journal, 2001, vol. 2, no 2, November 2001, pp. 95-107.

[5] A. A. Tunik and O. A. Sushchenko, "Usage of vector parametric optimization for robust stabilization of ground vehicles information-measuring devices," Proceedings of the National Aviation University, 2013, no. 4, pp. 23-32. https://doi.org/10.18372/2306-1472.57.5530

[6] O. A. Sushchenko, "Computer-aided design of robust system for stabilization of information-measuring devices at moving base," Proceedings of the National Aviation University, 2013, no. 3, pp. 41-48. https://doi.org/10.18372/2306-1472.56.5419 
[7] O. A. Sushchenko, "Osoblivosti linearizatsii sistemi stabilizatsii ruchomogo nazemnogo ob'ekta," Elektronika ta Sistemi Upravlinnya, 2008, no. №1(15), pp. 62-66.

[8] O. A. Sushchenko, "Computer-aided procedures assigned for design of robust inertially stabilized platforms," Electronics and Control Systems, 2017, no. 4, pp. 64-70. https://doi.org/10.18372/19905548.54.12320

[9] O. A. Sushchenko and Y. V. Beliavtsev, "Robust synthesis of two-degree-of-freedom system for stabilization of ground vehicle," Proceedings 2017 IEEE First Ukraine Conference on ELECTRICAL AND COMPUTER ENGINEERING (UKRCON), May 29 - June 2, 2017 Kyiv, Ukraine pp. 10311037.

https://doi.org/10.1109/UKRCON.2017.8100407
[10] I. Landau and G. Zito, Digital control systems. Design, identification and implementation. London: Springer-Verlag, 2006, 484 p.

[11] M. S. Medvedev and V. G. Potemkin, Control System Toolbox, Moscow: Dialog-MIFI, 1999, 287 p.

[12]D. P. Derevitsky and A. L. Fradkov, Applied Theory of Adaptive Control Systems, Moscow: Nauka, 1981, $216 \mathrm{p}$.

[13] V. M. Perelmuter, Packages of MATLAB Extension: Control System and Robust Control Toolboxes, Moscow: SOLON-PRESS, 2008, 224 p.

[14] V. A. Besekersky and E. P. Popov, Theory of Automatic Regulation Systems, Moscow: Nauka, $1975,768 \mathrm{p}$.

[15] V. V. Kochergin, Servo Systems with motors of Direct Current, Leningrad: Energoatomidat, 1988, $68 \mathrm{p}$.

Received September 04, 2020

Sushchenko Olha. orcid.org/0000-0002-8837-1521. Doctor of Engineering. Professor.

Faculty of Air Navigation, Electronics and Telecommunications, National Aviation University, Kyiv, Ukraine.

Education: Kyiv Polytechnic Institute, Kyiv, Ukraine, (1980).

Research area: systems for stabilization of information-measuring devices operated at vehicles of the wide class.

Publications: 250.

E-mail: sushoa@ukr.net

Salyuk Alexander. Bachelor.

Faculty of Air Navigation, Electronics and Telecommunications, National Aviation University, Kyiv, Ukraine.

Education: National Aviation University, Kyiv (2019).

Research area : information-measuring devices.

Publications: 1.

E-mail: sashalok511@gmail.com

Yehorov Serhey. Senior teacher.

Faculty of Air Navigation, Electronics and Telecommunications, National Aviation University, Kyiv, Ukraine.

Education: Kharkiv Aviation Institute, (1979).

Research area: control and avionics systems.

Publications: 30 .

E-mail: avionika2006@ukr.net

О. А. Сущенко, О. О. Салюк, С. Г. Сгоров. Особливості моделювання цифрової системи стабілізації обладнання наземного рухомого об'скта

Розглянуто особливості розробки моделей і моделювання системи стабілізації обладнання наземних рухомих об'єктів. Зазначено особливості процедури оптимального синтезу системи розглянутого типу. Основна мета дослідження - вивчення можливості проектування системи стабілізації 3 цифровим блоком управління. Представлені два підходи до дискретизації системи 3 цифровим блоком управління і дані відповідні блоксхеми. Дано аналіз методів дискретизації і відповідного програмного забезпечення. Обговорюються можливі програмні реалізації передавальних функцій в моделі цифрового блоку управління. Запропоновано особливості подання цифрових фільтрів. Проведено моделювання системи стабілізації з цифровим блоком управління. Представлені результати моделювання. Представлені перехідні процеси по кутовий швидкості 3 різними способами дискретизації. Результати порівняльного аналізу різних способів дискретизації представлені в табличній формі. Отримані результати можуть бути корисні при проектуванні систем управління широкого типу.

Ключові слова: Цифровий блок управління; цифровий фільтр; дискретизація; обладнання наземного рухомого об'єкта; система стабілізації.

Сущенко Ольга Андріївна. orcid.org/0000-0002-8837-1521. Доктор технічних наук. Професор.

Факультет аеронавігації, електроніки та телекомунікацій, Національний авіаційний університет, Київ, Україна. Освіта: Київський політехнічний інститут, Київ, Україна, (1980).

Напрям наукової діяльності: системи стабілізації інформаційно-вимірювальних пристроїв, експлуатованих на 
рухомих об'єктах широкого класу.

Кількість публікацій: 250.

E-mail: sushoa@ukr.net

Салюк Олександр Олексійович. Бакалавр.

Факультет аеронавігації, електроніки та телекомунікацій, Національний авіаційний університет, Київ, Україна. Освіта: Національний авіаційний університет, Київ (2019).

Напрям наукової діяльності: інформаційно-вимірювальні прилади.

Кількість публікацій :1.

E-mail: sashalok511@gmail.com

Сгоров Сергій Гаврилович. Старший викладач.

Факультет аеронавігації, електроніки та телекомунікацій, Національний авіаційний університет, Київ, Україна. Освіта: Харківський авіаційний інститут, (1979).

Напрям наукової діяльності: системи та процеси управління.

Кількість публікацій: 30.

E-mail: avionika2006@ukr.net

О. А. Сущенко, А. А. Салюк, С. Г. Егоров. Особенности моделирования цифровой системы стабилизации оборудования наземного подвижного объекта

Рассмотрены особенности разработки моделей и моделирования системы стабилизации оборудования наземных подвижных объектов. Отмечены особенности процедуры оптимального синтеза системы рассматриваемого типа. Основная цель исследования - изучение возможности проектирования системы стабилизации с цифровым блоком управления. Представлены два подхода к дискретизации системы с цифровым блоком управления и даны соответствующие блок-схемы. Дан анализ методов дискретизации и соответствующего программного обеспечения. Обсуждаются возможные программные представления передаточных функций в модели цифрового блока управления. Предложены особенности представления цифровых фильтров. Проведено моделирование системы стабилизации с цифровым блоком управления. Представлены результаты моделирования. Представлены переходные процессы по угловой скорости с разными способами дискретизации. Результаты сравнительного анализа различных способов дискретизации представлены в табличной форме. Полученные результаты могут быть полезны при проектировании систем управления широкого типа.

Ключевые слова: Цифровой блок управления; цифровой фильтр; дискретизации; оборудование наземного подвижного объекта; система стабилизации.

Сущенко Ольга Андреевна. orcid.org/0000-0002-8837-1521. Доктор технических наук. Профессор.

Факультет аэронавигации, электроники и телекоммуникаций, Национальный авиационный университет, Киев, Украина.

Образование: Киевский политехнический институт, Киев, Украина, (1980).

Направление научной деятельности: системы стабилизации информационно-измерительных устройств, эксплуатируемых на подвижных объектах широкого класса.

Количество публикаций: 250.

E-mail: sushoa@ukr.net

Салюк Александр Алексеевич. Бакалавр.

Факультет аэронавигации, электроники и телекоммуникаций, Национальный авиационный университет, Киев, Украина.

Образование: Национальный авиационный университет, Киев (2019).

Направление научной деятельности: информационно-измерительные приборы.

Количество публикаций: 1 .

E-mail: sashalok511@gmail.com

Егоров Сергей Гаврилович. Старший преподаватель.

Факультет аэронавигации, электроники и телекоммуникаций, Национальный авиационный университет, Киев, Украина.

Образование: Харьковский авиационный институт, (1979).

Направление научной деятельности: системы и процессы управления.

Количество публикаций: 30.

E-mail: avionika2006@ukr.net 